\title{
Multivariate dynamics of Spanish universities in international rankings
}

\author{
María-Teresa Gómez-Marcos; Marcelo Ruiz-Toledo; María-Purificación Vicente- \\ Galindo; Helena Martín-Rodero; Claudio Ruff-Escobar; María-Purificación Galindo- \\ Villardón
}

Nota: Este artículo se puede leer en español en:

http://www.profesionaldelainformacion.com/contenidos/2021/mar/gomez-ruiz-vicente-martin-ruff-galindo_es.pdf

How to cite this article:

Gómez-Marcos, María-Teresa; Ruiz-Toledo, Marcelo; Vicente-Galindo, María-Purificación; Martín-Rodero, Helena; Ruff-Escobar, Claudio; Galindo-Villardón, María-Purificación (2021). "Multivariate dynamics of Spanish universities in international rankings". Profesional de la información, v. 30, n. 2, e300210.

https://doi.org/10.3145/epi.2021.mar.10

Article received January $21^{\text {st }} 2021$

Final acceptance: February $17^{\text {th }} 2021$

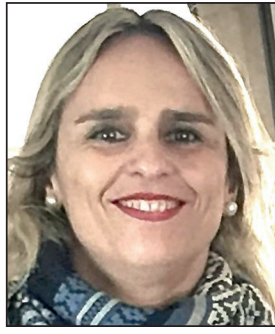

María-Teresa Gómez-Marcos

https://orcid.org/0000-0002-4368-7012

Universidad de Salamanca

Facultad de Medicina

Departamento de Estadística

Alfonso X El Sabio, $\mathrm{s} / \mathrm{n}$.

37007 Salamanca, Spain

mgomezma@usal.es

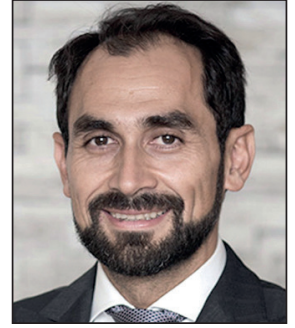

Marcelo Ruiz-Toledo

https://orcid.org/0000-0003-1865-7839

Universidad de Salamanca

Departamento de Estadística

mruiz@usal.es

Universidad Bernardo O'Higgins

Avenida Viel, 1497. Santiago, Chile

mruiz@ubo.cl

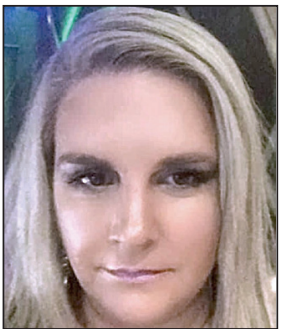

María-Purificación Vicente-Galindo https://orcid.org/0000-0002-5854-273X

Universidad de Salamanca

Facultad de Medicina

Departamento de Estadística

Alfonso X El Sabio, s/n.

37007 Salamanca, Spain

purivg@usal.es

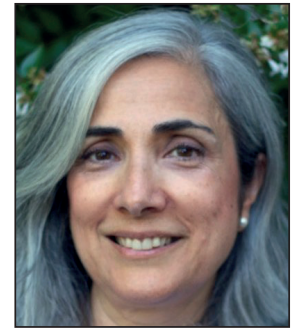

Helena Martín-Rodero

https://orcid.org/0000-0002-6698-9240

Universidad de Salamanca

Facultad de Medicina

Departamento de Estadística

Alfonso X El Sabio, $\mathrm{s} / \mathrm{n}$.

37007 Salamanca, Spain

helena@usal.es

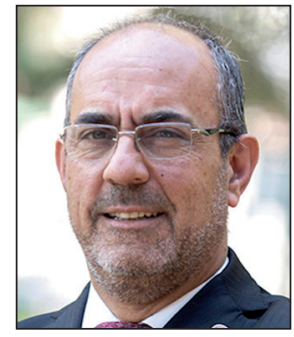

\section{Claudio Ruff-Escobar \\ https://orcid.org/0000-0003-1954-0800}

Universidad Bernardo O'Higgins

Avenida Viel, 1497. Santiago, Chile

cruff@ubo.cl

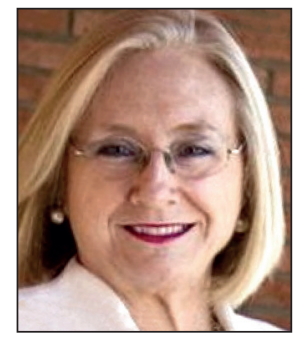

\begin{abstract}
Global rankings help boost the international reputation of universities, which thus attempt to achieve good positions on them. These rankings attract great interest each year and are followed attentively by stakeholders in higher education. This paper investigates the trajectory of Spanish universities in the ARWU and THE rankings over the last 5 years using the dynamic biplot technique to study the relationship between a multivariate dataset obtained at more than one time point. The results demonstrate that Spanish universities achieve low positions on international rankings when analyzed using this multivariate and dynamic approach. Indeed, only a small percentage occupy good positions in both studied rankings and stand out in terms of some of the indicators, whereas most achieve weak scores in the global context. Spanish universities should attempt to improve this situation, since the prestige resulting from a good position on these lists will always be beneficial in terms of the visibility of both the universities themselves and the whole Spanish university system.
\end{abstract}




\section{Keywords}

Higher education; Internationalization; World class; Universities; Shanghai Ranking; ARWU; THE; Dynamic biplot; Biplot; Spanish universities.

\section{Introduction}

The international landscape of higher education has experienced a great boost in recent years due to the globalization and commodification of knowledge (Knight, 2004). The educational market has become universal, borders have disappeared, and barriers have become blurred. To compete in this new scenario, universities need to improve their global positioning by designing strategies to increase their visibility and project their offering, capabilities, and appeal (Vázquez-García, 2015).

Internationalization can be defined as the inclusion of the international dimension into a university's strategy regarding its teaching, research, and transfer missions, as well as the projection of its offering and capabilities (Knight, 2004). This is, therefore, a concept with multiple manifestations, including the expansion of an organization's visibility, recognition, and scope of action. One element to help promote this type of internationalization is university rankings, acting as a stage on which the competition to achieve global status is played out (Rodríguez-Espinar, 2018). These classifications are now impossible to ignore and are presented as arbiters of universal academic excellence (Vázquez-García, 2015). Their substantial impact on the internationalization of universities has been the subject of numerous investigations (Marginson, 2012; Ordorika, Rodríguez-Gómez, 2010; De-Wit, 2017; Knight, 2014; Collins; Park, 2016). Although the main classifications available worldwide include few indicators that measure the degree of internationalization, achieving a good position in them has a great influence on world prestige, which in turn is independent of the degree of internationalization exhibited by the functions of that organization (Casani; Rodríguez-Pomeda, 2017).

The first two rankings to be established were the Academic Ranking of World Universities (ARWU) and the Times Higher Education World University Rankings (THE), and these are still considered to be two of the best known and most influential today (Safón, 2012; Marginson, 2007; Locke et al., 2008; Ordorika; Rodríguez-Gómez, 2010; Rauhvargers, 2011). They were later joined by others such as the QS World University Rankings, which split off from the THE ranking in 2010, and the SCImago Institutions Ranking and Leiden World Ranking, which focus exclusively on research results.

\section{Academic Ranking of World Universities (ARWU)}

The ARWU was published for the first time in 2003 under the name Shanghai Jiao Tong Academic Ranking of World Universities, being produced by the Jiao Tong University (China) Center for World-Class Universities (CWCU), which is why it is popularly known as the Shanghai Ranking. It ranks universities based on four criteria:

- teaching quality $(10 \%)$

- academic staff quality (40\%)

- research output (40\%)

- organization size (10\%)

Teaching quality is measured by the number of alumni who have received a Nobel Prize or Fields Medal (10\%). Furthermore, to measure the quality of the teaching staff, the total number of staff who have won Nobel Prizes in physics, chemistry, medicine, and economics or Fields Medals in mathematics (20\%) is considered. Similarly, to measure the quality of the teaching staff, the number of highly cited researchers according to the list published by Clarivate Analytics $(20 \%)$ is measured. Because of this indicator, such researchers have become an important asset to their universities and a frenzied race for their recruitment has ensued (Docampo; Torres-Salinas, 2013).

Research output is determined based on the number of Nature and Science articles published (20\%) and the number of articles indexed in the Science Citation Index Expanded (SCIE) and Social Sciences Citation Index (SSCI) over the previous five years (20\%). The final criterion in the ranking is the size of the organization (10\%).

The ARWU is the only international ranking that obtains its data independently of the analyzed institutions (Montané-López; Beltrán-Llavador; Teodoro, 2017). The main criticisms leveled at this ranking focus on its research-oriented indicators (Ordorika, 2015; Tomàs-Folch et al., 2015) and the inclusion of the Nobel Prize winner category, as these exclude a large number of universities from classification (Yong-Amaya; Zambrano-Zambrano; Ruso-Armada, 2018). Despite this criticism and some reluctance, it has become the basic reference worldwide (Docampo et al., 2012) and is considered to be the most outstanding academic classification on the global stage (Docampo; Cram, 2015).

\section{THE World University Ranking}

The next international ranking to emerge in the field of higher education was the THE ranking, created by the company Times Higher Education in 2010. The THE ranking is based on 13 indicators, grouped into five dimensions:

- teaching (30\%)

- research (30\%)

- citations (30\%)

- international perspective $(7.5 \%)$

- income from industry (2.5\%). 
The teaching dimension is determined through five variables, although the survey on the reputation of teachers and researchers accounts for half the weighting in this dimension (15\%). It also measures:

- teacher-to-student ratio $(4.5 \%)$

- proportion of doctoral students and graduates $(2.25 \%)$

- percentage of doctoral students and professors (6\%)

- institutional income (2.25\%).

The research dimension is determined by three variables:

- researcher reputation, collected via surveys with academics (18\%)

- research income per academic (6\%)

- scientific output, quantified by the number of publications indexed in Scopus per academic (6\%).

The research impact is also determined based on the citations received in publications indexed in Scopus (30\%).

The two concepts with least weight in this ranking are international perspective and knowledge transfer. The former is measured by:

- percentage of international students $(2.5 \%)$

- percentage of international staff (2.5\%)

- co-authorship of international works published in the last five years (2.5\%).

The latter captures the research income obtained from industry (2.5\%).

One of the major criticisms leveled at this ranking is motivated by the fact that it is largely based on reputation surveys and confidential data provided by universities (Sanz-Casado, 2015). Further criticism stems from the incomplete and confusing research income component since it is not standardized across countries (Marginson, 2014).

Although considered to be the most influential, neither of these international rankings include indicators with a high weighting for internationalization. Indeed, the $A R W U$ ranking does not include any variables that directly measure this concept (Delgado-Márquez; Hurtado-Torres; Bondar, 2011), while the THE ranking does include such an internationalization indicator but gives it a low weighting in the overall ranking (7.5\%). Despite this, both classifications are considered key for measuring projection at the global level and have a strong impact on national and institutional policies and strategies for the internationalization of higher education organizations (Collins; Park, 2016; De-Wit, 2017).

This link between rankings and internationalization strategies has resulted in differentiation within national systems through the separation of an elite sector made up of world-class universities and another consisting of more locally oriented, national establishments (De-Wit; Altbach, 2020). World-class universities are characterized by high-ranking research, a culture of excellence, and a brand that transcends national borders (Douglass, 2014). They are positioned in the upper echelons of international rankings and are recognized not only by other universities but also outside the education sector. Their reputation for research and teaching makes it easy for them to operate in a global market and to internationalize many of their functions (Douglass, 2016).

Global rankings are closely followed each year by different stakeholders in higher education. Achieving a high ranking sparks great interest, even in Spanish universities. The promotion of internationalization through rankings can lead to increased visibility and thereby enhance the image of the whole Spanish university system (Pérez-Esparrells, 2017). The purpose of the current study is to examine the positioning of Spanish institutions in two global rankings, as well as their trajectory over the last 5 years. The aim is to identify the institutions that have managed to be classified in the global rankings and those that can aspire to compete in the world-class group, as well as to analyze their trajectory and distinctive characteristics.

\section{Methodology}

International rankings have been the subject of numerous investigations focusing on the identification of the correlations and contributions of different indicators. Techniques such as factor analysis (Luque-Martínez; Faraoni; Doña-Toledo, 2018), principal components (Docampo; Cram, 2015), regression analysis (Safón, 2019), and correlation analysis (Shehatta; Mahmood, 2016) have been applied to study such classifications exhaustively. However, it is noted that the research literature lacks studies focused on the use of dynamic multivariate methods to observe the international projection of universities over time.

To carry out this research, the two oldest and most well-known global rankings were selected, viz. the ARWU and THE ranking. The $A R W U$ is based on objective data, while the THE ranking uses reputation surveys. This also means that these two classification systems can provide a complementary snapshot of university internationalization. The following websites for the rankings were used as sources for the database design:

- Academic Ranking of World Universities (ARWU)

http://www.shanghairanking.com

- Times Higher Education World University Rankings (THE)

http://www.timeshighereducation.com/world-university-rankings 
The values of the variables for Spanish universities were collected for the years 2016 to 2020 .

Dynamic biplots were selected as the technique to evaluate the relationship between the multivariate dataset analyzed at more than one time point. This technique was proposed by Egido-Miguélez (2015) as an extension of biplot methods to treat three-way data, offering the advantage that, instead of taking a consensus matrix as a reference, any of the individual matrices can be chosen and the corresponding trajectories studied. The three-way data of the matrix include:

- rows corresponding to universities

- columns corresponding to the indicators of each ranking

- the situation at various time points.

The dynamic biplot is developed in two stages:

- biplot analysis of the two-way data matrix for the reference year

- projection on the biplot graph obtained in the previous stage of the remaining time points to be studied, revealing their trajectory throughout different contexts.

The first step studies the multivariate correlations between variables and individuals, or both, while the second step captures the dynamic nature of the analysis.

The dynamic biplot technique can be applied using any factorization, but the best simultaneous representation of the trajectory of variables and points is provided by the HJ-biplot, as it can represent both types of elements with the highest quality (Egido-Miguélez, 2015). The HJ-biplot (Galindo-Villardón, 1986) simultaneously represents the universities and indicators from each ranking on a plane, where the similarity between universities is inversely proportional to the Euclidean distance between them. Meanwhile, the angles between indicators enable an assessment of the degree of covariation:

- acute angles indicate direct correlation

- obtuse angles indicate inverse correlation

- right angles indicate independence.

The length of the vectors approximates the standard deviation of the indicators.

The order of the orthogonal projections of each row marker onto a column marker approximates the order of each row elements (universities) in that column (indicator). The larger the projection of a point onto a vector, the more a university deviates from the mean of that variable.

The reference axes of the biplot plane on which the universities and indicators are represented are the principal components obtained as eigenvectors of the covariance matrix between indicators. The associated eigenvalues enable an assessment of the amount of information that each biplot plane explains (the explained variance). The angle that each indicator makes with the axis of factor 1 and 2 is known as the contribution of each factor to the variability of that indicator, whereas the sum of the two contributions determines the quality of the representation in the factor plane.

The analysis was carried out using $R$ with the dynBiplotGUI package, created by Egido-Miguélez (2015). The dynamic biplot technique finds application in the field of economics, but to the best of the authors' knowledge, it has not been applied to analyze universities based on their performance in rankings.

\section{Results}

For both international classifications, all the Spanish universities and their weighted indicators were analyzed. To provide an initial overview, the mean and rate of change of each university for each of the variables were calculated. The reference situation used to construct the biplot was set as the year 2020, corresponding to the most recent situation and, therefore, the most interesting for this study. The data for the reference period were centered and standardized.

Table 1. Universities included in the $A R W U$ and THE rankings

\begin{tabular}{|c|c|}
\hline$A R W U$ & THE \\
\hline Barcelona & Pompeu Fabra \\
\hline València & Autònoma de Barcelona \\
\hline Complutense de Madrid & Barcelona \\
\hline Granada & Autónoma de Madrid \\
\hline Autònoma de Barcelona & Navarra \\
\hline Autónoma de Madrid & València \\
\hline País Vasco & Complutense de Madrid \\
\hline Politècnica de València & Rovira i Virgili \\
\hline Pompeu Fabra & Alcalá de Henares \\
\hline Santiago de Compostela & País Vasco \\
\hline Rovira i Virgili & Granada \\
\hline \multirow[t]{14}{*}{ Politècnica de Catalunya } & La Laguna \\
\hline & Oviedo \\
\hline & Politècnica de Catalunya \\
\hline & Salamanca \\
\hline & Santiago de Compostela \\
\hline & A Coruña \\
\hline & Carlos III de Madrid \\
\hline & Castilla La Mancha \\
\hline & Murcia \\
\hline & Politècnica de València \\
\hline & Sevilla \\
\hline & Politécnica de Madrid \\
\hline & Vigo \\
\hline & Zaragoza \\
\hline
\end{tabular}


In the HJ-biplot graphs, the indicators are represented by vectors, while the universities are identified by points, labeled by their abbreviated name. Table 1 presents the universities that were included in the two rankings over the 5-year period, ordered according to their position in 2020.

There are 12 universities classified in the $A R W U$, and 25 universities in the THE ranking. Therefore, it is easier for Spanish institutions to be included in the latter classification.

\subsection{The ARWU}

Table 2 presents the results for the indicators of the ARWU ranking in each year for each university, as well as their mean and rate of change.

Table 2. ARWU indicators, averages, and rates of change (2016-2020)

\begin{tabular}{|c|c|c|c|c|c|c|}
\hline University & Year & Alumni & $\mathrm{HiCi}$ & $N \& S$ & PUB & $\mathbf{P C P}$ \\
\hline \multirow{5}{*}{ Autònoma de Barcelona } & 2016 & 0.00 & 0.00 & 12.10 & 45.20 & 20.70 \\
\hline & 2017 & 0.00 & 0.00 & 13.20 & 46.30 & 21.60 \\
\hline & 2018 & 0.00 & 0.00 & 11.20 & 47.80 & 22.70 \\
\hline & 2019 & 0.00 & 7.30 & 11.30 & 48.50 & 23.40 \\
\hline & 2020 & 0.00 & 9.90 & 12.30 & 46.70 & 23.30 \\
\hline Average & & & 3.44 & 12.02 & 46.90 & 22.34 \\
\hline Rate of change & & & & $1.65 \%$ & $3.32 \%$ & $12.56 \%$ \\
\hline \multirow{5}{*}{ Autónoma de Madrid } & 2016 & 0.00 & 14.50 & 10.90 & 38.40 & 18.40 \\
\hline & 2017 & 0.00 & 10.90 & 12.40 & 39.00 & 18.70 \\
\hline & 2018 & 0.00 & 9.60 & 12.80 & 40.30 & 19.50 \\
\hline & 2019 & 0.00 & 7.30 & 12.60 & 40.70 & 19.40 \\
\hline & 2020 & 0.00 & 7.00 & 11.60 & 40.00 & 19.30 \\
\hline Average & & & 9.86 & 12.06 & 39.68 & 19.06 \\
\hline Rate of change & & & $-51.72 \%$ & $6.42 \%$ & $4.17 \%$ & $4.89 \%$ \\
\hline \multirow{5}{*}{ Barcelona } & 2016 & 0.00 & 17.80 & 12.00 & 50.60 & 19.90 \\
\hline & 2017 & 0.00 & 15.40 & 12.30 & 51.00 & 20.40 \\
\hline & 2018 & 0.00 & 27.10 & 12.50 & 53.30 & 23.20 \\
\hline & 2019 & 0.00 & 24.30 & 13.30 & 51.30 & 21.90 \\
\hline & 2020 & 0.00 & 22.10 & 12.90 & 50.70 & 21.70 \\
\hline Average & & & 21.34 & 12.60 & 51.38 & 21.42 \\
\hline Rate of change & & & $24.16 \%$ & $7.50 \%$ & $0.20 \%$ & $9.05 \%$ \\
\hline \multirow{5}{*}{ Complutense de Madrid } & 2016 & 19.20 & 0.00 & 9.10 & 42.30 & 13.20 \\
\hline & 2017 & 19.00 & 0.00 & 9.80 & 41.90 & 13.50 \\
\hline & 2018 & 19.00 & 0.00 & 12.20 & 44.00 & 14.50 \\
\hline & 2019 & 17.70 & 10.40 & 12.60 & 43.90 & 14.90 \\
\hline & 2020 & 17.20 & 9.90 & 11.00 & 45.10 & 15.30 \\
\hline Average & & 18.42 & 4.06 & 10.94 & 43.44 & 14.28 \\
\hline Rate of change & & $-10.42 \%$ & & $20.88 \%$ & $6.62 \%$ & $15.91 \%$ \\
\hline \multirow{5}{*}{ Granada } & 2016 & 0.00 & 22.90 & 5.30 & 40.70 & 16.00 \\
\hline & 2017 & 0.00 & 24.40 & 6.20 & 40.30 & 16.40 \\
\hline & 2018 & 0.00 & 23.50 & 4.20 & 40.80 & 16.30 \\
\hline & 2019 & 0.00 & 23.20 & 5.30 & 41.60 & 16.10 \\
\hline & 2020 & 0.00 & 21.00 & 6.30 & 42.60 & 16.40 \\
\hline Average & & & 23.00 & 5.46 & 41.20 & 16.24 \\
\hline Rate of change & & & $-8.30 \%$ & $18.87 \%$ & $4.67 \%$ & $2.50 \%$ \\
\hline \multirow{5}{*}{ País Vasco } & 2016 & 0.00 & 0.00 & 9.20 & 36.40 & 14.40 \\
\hline & 2017 & 0.00 & 0.00 & 11.70 & 37.30 & 15.30 \\
\hline & 2018 & 0.00 & 9.60 & 12.20 & 38.10 & 16.60 \\
\hline & 2019 & 0.00 & 0.00 & 11.60 & 39.20 & 16.40 \\
\hline & 2020 & 0.00 & 7.00 & 12.50 & 38.80 & 16.90 \\
\hline Average & & & 3.32 & 11.44 & 37.96 & 15.92 \\
\hline Rate of change & & & & $35.87 \%$ & $6.59 \%$ & $17.36 \%$ \\
\hline
\end{tabular}




\begin{tabular}{|c|c|c|c|c|c|c|}
\hline University & Year & Alumni & $\mathrm{HiCi}$ & $N \& S$ & PUB & PCP \\
\hline \multirow{5}{*}{ Politècnica de Catalunya } & 2016 & 0.00 & 14.50 & 8.00 & 27.70 & 15.80 \\
\hline & 2017 & 0.00 & 0.00 & 6.40 & 27.70 & 14.10 \\
\hline & 2018 & 0.00 & 0.00 & 6.00 & 27.70 & 14.20 \\
\hline & 2019 & 0.00 & 0.00 & 6.70 & 28.20 & 14.60 \\
\hline & 2020 & 0.00 & 0.00 & 4.50 & 27.80 & 14.40 \\
\hline Average & & & 2.90 & 6.32 & 27.82 & 14.62 \\
\hline Rate of change & & & & $-43.75 \%$ & $0.36 \%$ & $-8.86 \%$ \\
\hline \multirow{5}{*}{ Politècnica de València } & 2016 & 0.00 & 17.80 & 7.60 & 31.80 & 16.10 \\
\hline & 2017 & 0.00 & 10.90 & 7.50 & 32.40 & 15.30 \\
\hline & 2018 & 0.00 & 9.60 & 8.90 & 32.40 & 15.10 \\
\hline & 2019 & 0.00 & 10.40 & 8.20 & 34.20 & 15.10 \\
\hline & 2020 & 0.00 & 14.00 & 8.00 & 34.00 & 15.80 \\
\hline Average & & & 12.54 & 8.04 & 32.96 & 15.48 \\
\hline Rate of change & & & $-21.35 \%$ & $5.26 \%$ & $6.92 \%$ & $-1.86 \%$ \\
\hline \multirow{5}{*}{ Pompeu Fabra } & 2016 & 0.00 & 0.00 & 19.70 & 27.20 & 34.30 \\
\hline & 2017 & 0.00 & 10.90 & 20.10 & 27.80 & 37.70 \\
\hline & 2018 & 0.00 & 13.50 & 20.10 & 28.50 & 39.40 \\
\hline & 2019 & 0.00 & 0.00 & 19.70 & 28.90 & 36.30 \\
\hline & 2020 & 0.00 & 0.00 & 16.20 & 28.90 & 34.90 \\
\hline Average & & & 4.88 & 19.16 & 28.26 & 36.52 \\
\hline Rate of change & & & & $-17.77 \%$ & $6.25 \%$ & $1.75 \%$ \\
\hline \multirow{5}{*}{ Rovira i Virgili } & 2016 & 0.00 & 10.30 & 5.30 & 23.20 & 21.50 \\
\hline & 2017 & 0.00 & 0.00 & 4.90 & 23.80 & 20.30 \\
\hline & 2018 & 0.00 & 0.00 & 4.60 & 23.30 & 20.30 \\
\hline & 2019 & 0.00 & 7.30 & 5.20 & 24.60 & 22.00 \\
\hline & 2020 & 0.00 & 7.00 & 4.60 & 24.70 & 22.20 \\
\hline Average & & & 4.92 & 4.92 & 23.92 & 21.26 \\
\hline Rate of change & & & $-32.04 \%$ & $-13.21 \%$ & $6.47 \%$ & $3.26 \%$ \\
\hline \multirow{5}{*}{ Santiago de Compostela } & 2016 & 0.00 & 14.50 & 6.20 & 30.90 & 14.80 \\
\hline & 2017 & 0.00 & 15.40 & 6.90 & 31.30 & 15.50 \\
\hline & 2018 & 0.00 & 13.50 & 6.30 & 32.30 & 15.70 \\
\hline & 2019 & 0.00 & 7.30 & 5.80 & 32.60 & 14.90 \\
\hline & 2020 & 0.00 & 7.00 & 6.10 & 32.50 & 15.10 \\
\hline Average & & & 11.54 & 6.26 & 31.92 & 15.20 \\
\hline Rate of change & & & $-51.72 \%$ & $-1.61 \%$ & $5.18 \%$ & $2.03 \%$ \\
\hline \multirow{5}{*}{ València } & 2016 & 0.00 & 0.00 & 6.90 & 41.50 & 15.00 \\
\hline & 2017 & 0.00 & 0.00 & 5.50 & 43.00 & 15.70 \\
\hline & 2018 & 0.00 & 0.00 & 5.70 & 44.30 & 16.40 \\
\hline & 2019 & 0.00 & 14.70 & 6.90 & 45.40 & 17.20 \\
\hline & 2020 & 0.00 & 12.10 & 7.10 & 46.30 & 17.50 \\
\hline Average & & & 5.36 & 6.42 & 44.10 & 16.36 \\
\hline Rate of change & & & & $2.90 \%$ & $11.507 \%$ & $16.607 \%$ \\
\hline
\end{tabular}

HiCi (highly cited researchers), N \& S (Nature and Science articles), PUB (articles in SCIE and SSCI), PCP (size of organization).

The results presented in Table 2 show that the Universidad Complutense de Madrid was the only university that managed to achieve a position on the Alumni indicator with an average value of 18.42. The Universidad de Granada obtained the highest average on $\mathrm{HiCi}$ (23.00), the Universitat de Barcelona on PUB (51.38), and the Universitat Pompeu Fabra on N \& S (19.16) and PCP (36.52). Regarding the rate of change of each variable, the uni-
Global rankings have a great impact on the prestige and internationalization of universities. Universities that perform well in these classifications will have greater capacity to attract students and academics from other countries. 
versities that suffered the greatest decreases were the Autónoma de Madrid and Santiago de Compostela on $\mathrm{HiCi}(-51.72 \%)$ and Politècnica de Catalunya on N \& S (-43.75\%). The greatest positive variations were recorded for the Universitat de València on PUB (11.57\%) and the Universitat Politècnica de València on PCP (17.36\%).
Table 3. ARWU explained variance

\begin{tabular}{|c|c|c|c|}
\hline Axes & Eigenvalue & $\begin{array}{c}\text { Explained } \\
\text { variance }\end{array}$ & $\begin{array}{c}\text { Cumulative } \\
\text { variance }\end{array}$ \\
\hline Axis 1 & 4.55 & 37.65 & 37.65 \\
\hline Axis 2 & 4.30 & 33.62 & 71.27 \\
\hline Axis 3 & 3.37 & 20.58 & 91.85 \\
\hline
\end{tabular}

The information captured in the $\mathrm{HJ}$-biplot is presented in Table 3. Three axes were retained because a very high accumulated inertia (91.85\%) was achieved, being sufficient to characterize with some certainty the positioning of the universities in the $A R W U$ ranking with respect to all the variables considered.

Table 4 presents the contribution of each factor axis to the variability of the ranking indicators. The variable related to academics with Nobel Prizes or Fields Medals could not be included because no Spanish university obtained a score on it.

Table 4. Contribution of each factor axis to the variability of the ARWU indicators

\begin{tabular}{|l|c|c|}
\hline \multicolumn{1}{|c|}{ Variable } & Axis 1 & Axis 2 \\
\hline Alumni (alumni with Nobel Prize or Fields Medal) & 153 & 6 \\
\hline HiCi (highly cited researchers) & 708 & 1 \\
\hline N\& S (Nature and Science articles) & 0 & 901 \\
\hline PUB (articles in SCIE and SSCl) & 755 & 18 \\
\hline PCP (size of organization) & 266 & 75 \\
\hline
\end{tabular}

Considering the contributions of each factor to the entries in each column, it was observed that all the variables could be interpreted in the factor plane 1-2 or 1-3, resulting in a good quality of representation. PUB and HiCi made a strong contribution to axis 1 . Regarding $N \& S$, axis 2 provided information of interest, while axis 3 made the greatest contribution to axis 3.

Figure 1 shows the $\mathrm{HJ}$-biplot for the 2020 data matrix, providing the best possible knowledge regarding the reference. A strong and direct correlation is observed between $\mathrm{HiCi}$ and PUB, with the latter variable also covarying directly with $N$ $\& S$ and Alumni. The only indirect correlation appears between the PCP and HiCi indicators. However, the latter variable related to highly cited researchers presented independence from Alumni and a very weak connection with $N \& S$.

Regarding the ranks of the 12 universities analyzed, a good quality of representation was not obtained for only 2 , which are thus omitted from the factor planes. Universities were positioned in different parts of the graph, establishing various groups based on the similarity between their characteristics.

The Universitat de Barcelona, the best-classified Spanish university in the ARWU ranking, showed high values on the $\mathrm{HiCi}$ and PUB variables, each with a weighting of $20 \%$ in the final ranking. This university appeared close to the Universidades de València and Granada, which were ranked second and fourth, respectively. If we compare these po-
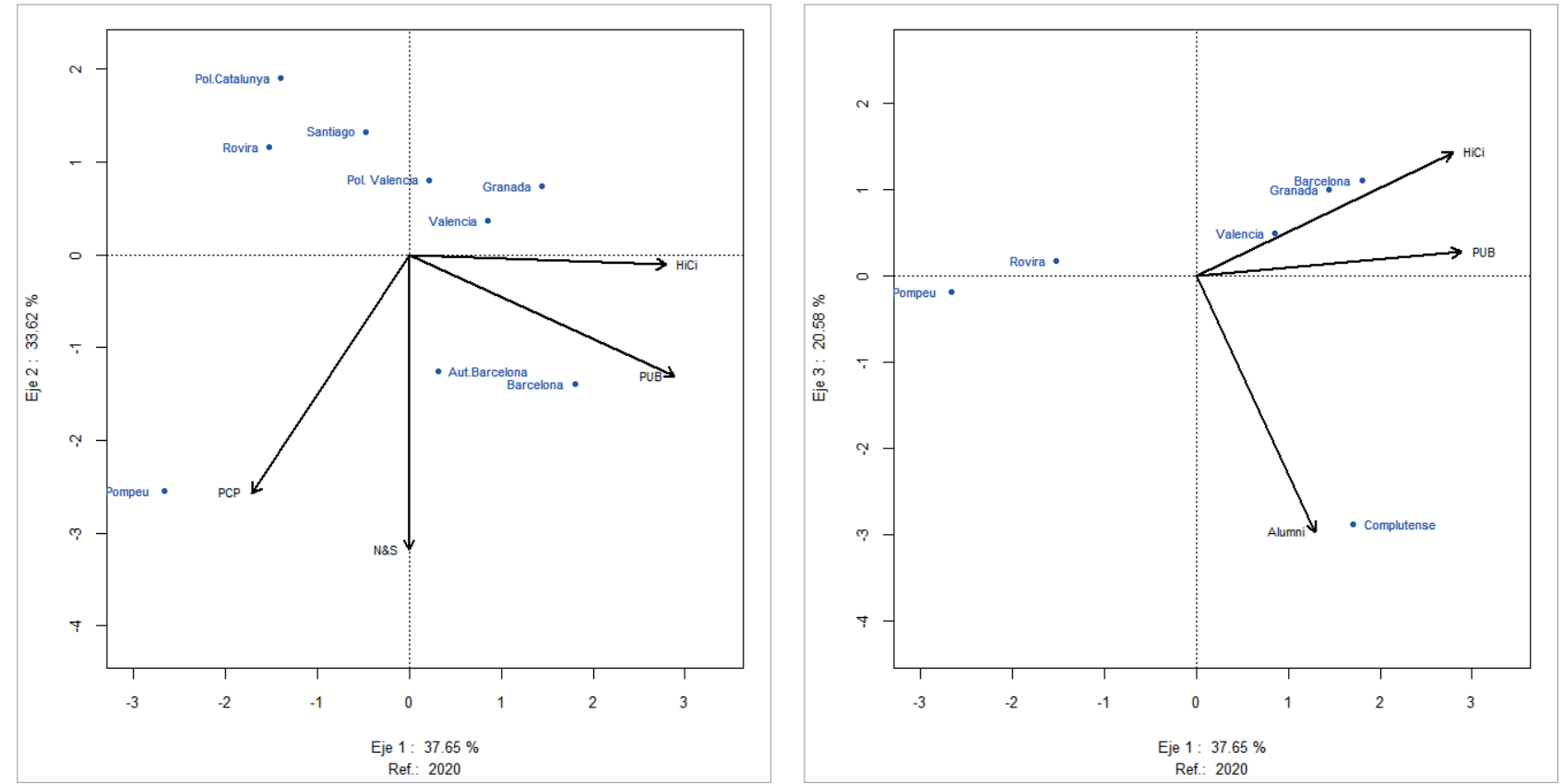

Figure 1. Factor representation HJ-biplots for the ARWU ranking (2020), planes 1-2 and 1-3. 
sitions with the averages and rates of change presented in Table 2, it is observed that the Universitat de Barcelona obtained the highest average value on PUB (51.38) and the Universidad de Granada on $\mathrm{HiCi}$ (23.00). However, the Universitat de València obtained a low average on this latter variable (5.36) because it failed to make the ranking in the first 3 years. Table 2 also demonstrates that the Universitat de Barcelona exhibited its highest rate of change on $\mathrm{HiCi}(24.16 \%)$, while the Universidad de Granada experienced a decrease (-8.30\%).

Universitat Pompeu Fabra, ranked ninth, stood out for its high values on the PCP indicator, which includes the size of the organization, calculated as a weighting on all the variables. Its average was also very high (36.52) on this indicator (Table 2), although the rate of change was not significant (1.75\%). The only university that stood out with high values for alumni with Nobel Prizes or Fields Medals (Alumni) was the Universi-

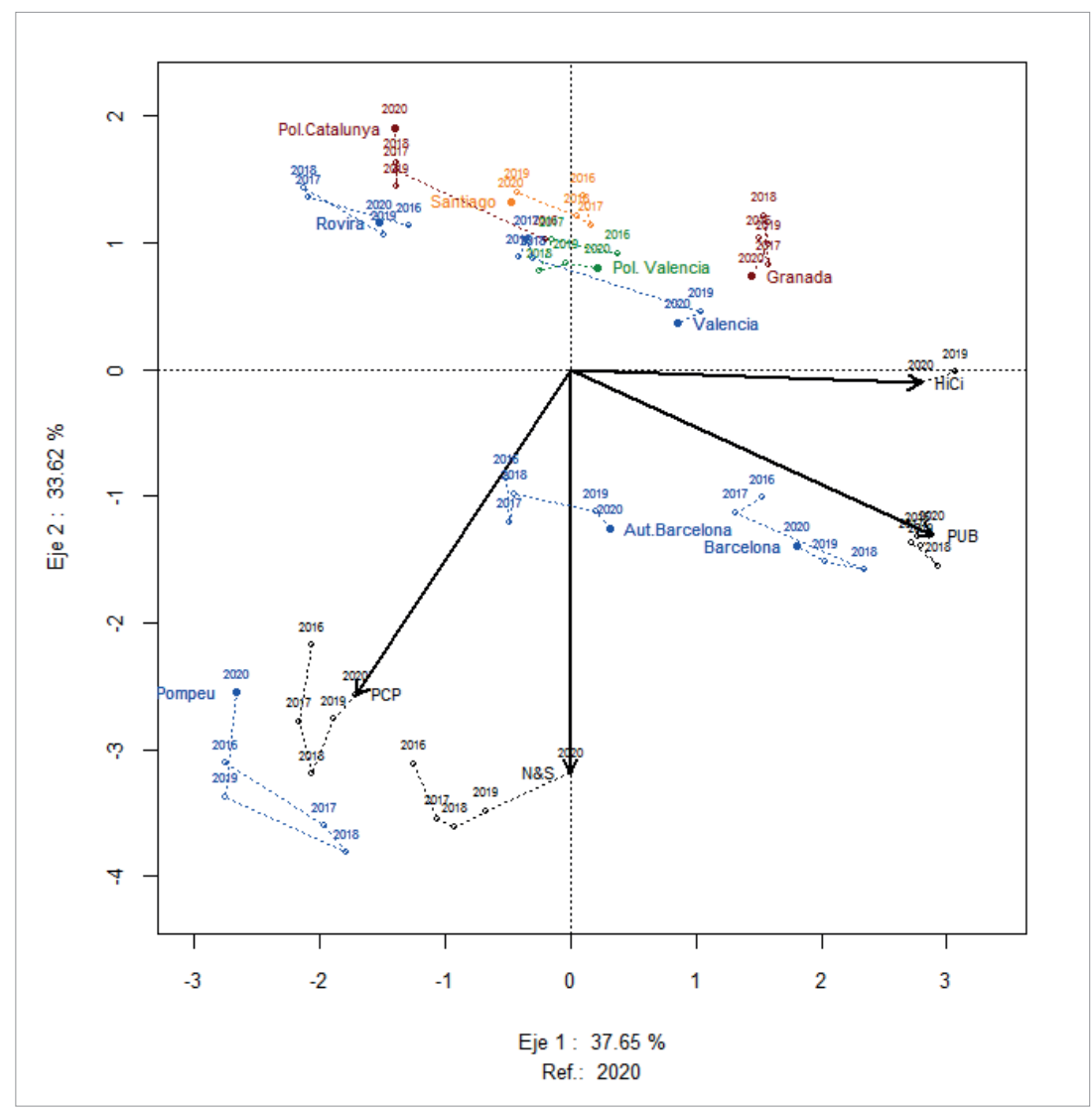

Figure 2. Dynamic biplot factorial representation of the ARWU ranking, plane 1-2. dad Complutense de Madrid, ranked third in the final ARWU list. The Universitat Autònoma de Barcelona was included based on the number of published articles in Nature and Science ( $N \& S$ ), a variable with a weighting of $20 \%$ in the ranking. Table 2 demonstrates that its average on this variable was also high (12.02), albeit below that of the Universitat Pompeu Fabra (19.16), Universitat de Barcelona (12.60), and Universidad Autónoma de Madrid (12.06). The Universitat Politècnica de València was close to the highly cited researchers indicator, while the last three institutions listed (Santiago de Compostela, Rovira i Virgili, and Politècnica de Catalunya) all appeared far from the indicators shown, thus indicating low values. Table 2 shows that these three organizations exhibited significant decreases according to the rates of change of some of the ranking indicators.

Figure 2 shows the dynamic biplot, projecting the situation of each university in each year according to its trajectory.

The Universitat de Barcelona showed the greatest increase in the value of the PUB variable during 2018, with a reduction in the subsequent two years. The Universitat Autònoma de Barcelona showed the greatest variation in its trajectory in terms of the indicators, as it was characterized by PCP in 2016, 2017, and 2018 but approached $N$ \& $S$ in subsequent years. The Universitat Pompeu Fabra showed an irregular trajectory but always characterized by the indicator related to organization size. Over the last two years, the Universitat de València showed considerable progress towards the highly cited researchers variable, thus approaching the Universidad de Granada, which exhibited a less pronounced trajectory. The other institutions generally showed trajectories that approached the variables but remained far from them.

In plane 1-3, the Universidad Complutense de Madrid was always characterized by the Alumni variable.

Global rankings are closely followed each by different stakeholders in higher education. Achieving a high ranking sparks great interest, even in Spanish universities 


\subsection{The THE Ranking}

Table 5 presents the results for the universities in the THE indicators for the different years, as well as the mean and rate of change for each.

Table 5. THE ranking indicators, averages, and rates of change (2016-2020)

\begin{tabular}{|c|c|c|c|c|c|c|}
\hline University & Year & Teaching & Research & Citations & Industry & $\begin{array}{l}\text { Internationa- } \\
\text { lization }\end{array}$ \\
\hline \multirow{5}{*}{ Alcalá } & 2016 & 17.60 & 11.20 & 28.30 & 43.30 & 50.00 \\
\hline & 2017 & 19.60 & 11.50 & 31.80 & 42.20 & 55.80 \\
\hline & 2018 & 20.40 & 12.20 & 45.90 & 40.50 & 59.80 \\
\hline & 2019 & 30.40 & 14.50 & 37.50 & 41.00 & 61.60 \\
\hline & 2020 & 18.50 & 15.70 & 43.20 & 42.50 & 59.00 \\
\hline Average & & 21.30 & 13.02 & 37.34 & 41.90 & 57.24 \\
\hline Rate of change & & $5.11 \%$ & $40.18 \%$ & $52.65 \%$ & $-1.85 \%$ & $18.00 \%$ \\
\hline \multirow{5}{*}{ Autònoma de Barcelona } & 2016 & 40.30 & 40.00 & 83.80 & 34.90 & 50.30 \\
\hline & 2017 & 39.40 & 36.40 & 86.70 & 39.90 & 52.30 \\
\hline & 2018 & 43.30 & 36.10 & 89.50 & 42.10 & 60.10 \\
\hline & 2019 & 43.90 & 36.50 & 92.40 & 41.30 & 62.20 \\
\hline & 2020 & 40.90 & 36.10 & 92.90 & 44.80 & 64.30 \\
\hline Average & & 41.56 & 37.02 & 89.06 & 40.60 & 57.84 \\
\hline Rate of change & & $1.49 \%$ & $-9.75 \%$ & $10.86 \%$ & $28.37 \%$ & $27.83 \%$ \\
\hline \multirow{5}{*}{ Autónoma de Madrid } & 2016 & 35.60 & 30.90 & 46.90 & 33.00 & 48.60 \\
\hline & 2017 & 32.30 & 28.30 & 57.40 & 35.80 & 51.60 \\
\hline & 2018 & 33.00 & 28.10 & 58.40 & 34.90 & 49.00 \\
\hline & 2019 & 33.90 & 28.40 & 64.80 & 37.80 & 51.10 \\
\hline & 2020 & 40.10 & 28.70 & 74.50 & 38.60 & 51.50 \\
\hline Average & & 34.98 & 28.88 & 60.40 & 36.02 & 50.36 \\
\hline Rate of change & & $12.64 \%$ & $-7.12 \%$ & $58.85 \%$ & $16.97 \%$ & $5.97 \%$ \\
\hline \multirow{5}{*}{ Barcelona } & 2016 & 38.50 & 37.40 & 78.90 & 31.10 & 49.20 \\
\hline & 2017 & 33.70 & 33.00 & 81.30 & 35.30 & 49.30 \\
\hline & 2018 & 32.40 & 32.50 & 83.20 & 34.00 & 50.60 \\
\hline & 2019 & 37.70 & 32.30 & 85.10 & 40.10 & 52.60 \\
\hline & 2020 & 37.30 & 32.50 & 87.60 & 41.20 & 54.70 \\
\hline Average & & 35.92 & 33.54 & 83.22 & 36.34 & 51.28 \\
\hline Rate of change & & $-3.12 \%$ & $-13.10 \%$ & $11.03 \%$ & $32.48 \%$ & $11.18 \%$ \\
\hline \multirow{5}{*}{ Castilla-La Mancha } & 2016 & 18.40 & 10.30 & 30.50 & 29.70 & 28.60 \\
\hline & 2017 & 16.80 & 10.80 & 35.30 & 34.30 & 30.50 \\
\hline & 2018 & 18.10 & 10.40 & 28.70 & 33.70 & 33.30 \\
\hline & 2019 & 20.30 & 11.70 & 31.10 & 35.90 & 35.20 \\
\hline & 2020 & 16.60 & 12.50 & 32.70 & 36.00 & 37.00 \\
\hline Average & & 18.04 & 11.14 & 31.66 & 33.92 & 32.92 \\
\hline Rate of change & & $-9.78 \%$ & $21.36 \%$ & $7.21 \%$ & $21.21 \%$ & $29.37 \%$ \\
\hline \multirow{5}{*}{ Carlos III de Madrid } & 2016 & 23.20 & 17.40 & 24.80 & 34.80 & 44.70 \\
\hline & 2017 & 24.70 & 15.90 & 29.60 & 37.20 & 53.10 \\
\hline & 2018 & 24.60 & 15.30 & 33.60 & 36.30 & 56.80 \\
\hline & 2019 & 26.40 & 16.00 & 37.30 & 37.80 & 58.60 \\
\hline & 2020 & 24.40 & 16.30 & 34.90 & 38.20 & 60.20 \\
\hline Average & & 24.66 & 16.18 & 32.04 & 36.86 & 54.68 \\
\hline Rate of change & & $5.17 \%$ & $-6.32 \%$ & $40.73 \%$ & $9.77 \%$ & $34.68 \%$ \\
\hline
\end{tabular}




\begin{tabular}{|c|c|c|c|c|c|c|}
\hline University & Year & Teaching & Research & Citations & Industry & $\begin{array}{l}\text { Internationa- } \\
\text { lization }\end{array}$ \\
\hline \multirow{5}{*}{ Complutense de Madrid } & 2016 & 33.20 & 27.60 & 31.20 & 30.90 & 39.10 \\
\hline & 2017 & 30.70 & 27.10 & 36.70 & 36.00 & 40.10 \\
\hline & 2018 & 35.20 & 27.40 & 38.50 & 33.50 & 41.70 \\
\hline & 2019 & 42.40 & 28.40 & 42.70 & 35.60 & 44.30 \\
\hline & 2020 & 35.40 & 28.90 & 47.20 & 36.10 & 44.00 \\
\hline Average & & 35.38 & 27.88 & 39.26 & 34.42 & 41.84 \\
\hline Rate of change & & $6.63 \%$ & $4.71 \%$ & $51.28 \%$ & $16.83 \%$ & $12.53 \%$ \\
\hline \multirow{5}{*}{ A Coruña } & 2016 & 18.30 & 10.00 & 16.60 & 38.20 & 23.40 \\
\hline & 2017 & 17.60 & 10.90 & 23.70 & 35.50 & 27.30 \\
\hline & 2018 & 19.10 & 11.20 & 23.70 & 34.30 & 30.60 \\
\hline & 2019 & 22.80 & 12.40 & 26.10 & 35.60 & 30.90 \\
\hline & 2020 & 20.30 & 13.70 & 32.50 & 36.30 & 31.60 \\
\hline Average & & 19.62 & 11.64 & 24.52 & 35.98 & 28.76 \\
\hline Rate of change & & $10.93 \%$ & $37.00 \%$ & $95.78 \%$ & $-4.97 \%$ & $35.04 \%$ \\
\hline \multirow{5}{*}{ Granada } & 2016 & 24.30 & 14.70 & 45.80 & 29.40 & 36.40 \\
\hline & 2017 & 21.90 & 16.80 & 46.30 & 33.20 & 43.10 \\
\hline & 2018 & 22.50 & 19.20 & 46.80 & 32.80 & 50.10 \\
\hline & 2019 & 23.50 & 19.00 & 48.30 & 35.00 & 47.00 \\
\hline & 2020 & 19.40 & 20.90 & 52.00 & 35.60 & 48.10 \\
\hline Average & & 22.32 & 18.12 & 47.84 & 33.20 & 44.94 \\
\hline Rate of change & & $-20.16 \%$ & $42.18 \%$ & $13.54 \%$ & $21.09 \%$ & $32.14 \%$ \\
\hline \multirow{5}{*}{ La Laguna } & 2016 & 16.90 & 10.00 & 44.80 & 28.50 & 44.70 \\
\hline & 2017 & 16.90 & 9.60 & 48.50 & 32.70 & 47.10 \\
\hline & 2018 & 18.10 & 9.70 & 57.50 & 32.40 & 46.60 \\
\hline & 2019 & 24.30 & 11.50 & 62.30 & 35.10 & 46.70 \\
\hline & 2020 & 19.30 & 11.50 & 67.80 & 35.20 & 46.90 \\
\hline Average & & 19.10 & 10.46 & 56.18 & 32.78 & 46.40 \\
\hline Rate of change & & $14.20 \%$ & $15.00 \%$ & $51.34 \%$ & $23.51 \%$ & $4.92 \%$ \\
\hline \multirow{5}{*}{ Murcia } & 2016 & 19.30 & 11.70 & 28.00 & 29.50 & 28.30 \\
\hline & 2017 & 18.40 & 12.70 & 31.00 & 33.50 & 32.00 \\
\hline & 2018 & 20.10 & 12.40 & 32.10 & 33.00 & 34.70 \\
\hline & 2019 & 27.40 & 13.20 & 32.20 & 35.30 & 37.60 \\
\hline & 2020 & 22.30 & 13.80 & 32.60 & 35.90 & 38.50 \\
\hline Average & & 21.50 & 12.76 & 31.18 & 33.44 & 34.22 \\
\hline Rate of change & & $15.54 \%$ & $17.95 \%$ & $16.43 \%$ & $21.69 \%$ & $36.04 \%$ \\
\hline \multirow{5}{*}{ Navarra } & 2016 & 31.90 & 20.80 & 57.50 & 63.50 & 52.60 \\
\hline & 2017 & 29.70 & 23.90 & 65.30 & 55.60 & 55.60 \\
\hline & 2018 & 27.90 & 24.50 & 74.60 & 63.90 & 59.70 \\
\hline & 2019 & 34.10 & 24.20 & 82.00 & 66.60 & 63.20 \\
\hline & 2020 & 30.40 & 27.90 & 80.30 & 85.50 & 65.10 \\
\hline Average & & 30.80 & 24.26 & 71.94 & 67.02 & 59.24 \\
\hline Rate of change & & $-4.70 \%$ & $34.13 \%$ & $39.65 \%$ & $34.65 \%$ & $23.76 \%$ \\
\hline \multirow{5}{*}{ Oviedo } & 2016 & 19.50 & 10.80 & 41.90 & 34.10 & 36.20 \\
\hline & 2017 & 18.30 & 12.40 & 44.20 & 33.40 & 30.50 \\
\hline & 2018 & 27.00 & 13.50 & 49.10 & 34.10 & 31.90 \\
\hline & 2019 & 25.50 & 14.70 & 50.80 & 38.00 & 34.10 \\
\hline & 2020 & 16.80 & 15.20 & 54.80 & 38.50 & 34.40 \\
\hline Average & & 21.42 & 13.32 & 48.16 & 35.62 & 33.42 \\
\hline Rate of change & & $-13.85 \%$ & $40.74 \%$ & $30.79 \%$ & $12.90 \%$ & $-4.97 \%$ \\
\hline
\end{tabular}




\begin{tabular}{|c|c|c|c|c|c|c|}
\hline University & Year & Teaching & Research & Citations & Industry & $\begin{array}{l}\text { Internationa- } \\
\text { lization }\end{array}$ \\
\hline \multirow{5}{*}{ País Vasco } & 2016 & 18.20 & 19.60 & 43.10 & 30.30 & 34.90 \\
\hline & 2017 & 20.90 & 14.30 & 50.20 & 34.70 & 37.90 \\
\hline & 2018 & 21.00 & 14.80 & 51.40 & 34.80 & 40.80 \\
\hline & 2019 & 20.40 & 16.50 & 50.00 & 36.20 & 40.10 \\
\hline & 2020 & 22.00 & 17.10 & 47.30 & 37.10 & 41.50 \\
\hline Average & & 20.50 & 16.46 & 48.40 & 34.62 & 39.04 \\
\hline Rate of change & & $20.88 \%$ & $-12.76 \%$ & $9.74 \%$ & $22.44 \%$ & $18.91 \%$ \\
\hline \multirow{5}{*}{ Politècnica de Catalunya } & 2016 & 25.20 & 14.80 & 44.70 & 40.90 & 63.90 \\
\hline & 2017 & 27.10 & 17.50 & 51.20 & 41.50 & 51.40 \\
\hline & 2018 & 27.10 & 17.60 & 55.30 & 41.60 & 53.20 \\
\hline & 2019 & 29.70 & 17.30 & 53.70 & 40.90 & 56.20 \\
\hline & 2020 & 23.70 & 17.20 & 56.90 & 41.20 & 59.10 \\
\hline Average & & 26.56 & 16.88 & 52.36 & 41.22 & 56.76 \\
\hline Rate of change & & $-5.95 \%$ & $16.22 \%$ & $27.29 \%$ & $0.73 \%$ & $-7.51 \%$ \\
\hline \multirow{5}{*}{ Politécnica de Madrid } & 2016 & 21.80 & 14.60 & 24.50 & 38.30 & 39.50 \\
\hline & 2017 & 21.90 & 13.70 & 30.80 & 39.10 & 41.90 \\
\hline & 2018 & 23.80 & 13.60 & 34.80 & 43.00 & 45.00 \\
\hline & 2019 & 31.10 & 13.90 & 37.90 & 42.60 & 47.50 \\
\hline & 2020 & 22.60 & 14.90 & 37.70 & 42.40 & 49.10 \\
\hline Average & & 24.24 & 14.14 & 33.14 & 41.08 & 44.60 \\
\hline Rate of change & & $3.67 \%$ & $2.05 \%$ & $53.88 \%$ & $10.70 \%$ & $24.30 \%$ \\
\hline \multirow{5}{*}{ Politècnica de València } & 2016 & 20.30 & 12.70 & 34.30 & 43.80 & 32.90 \\
\hline & 2017 & 22.10 & 24.80 & 43.90 & 44.30 & 41.90 \\
\hline & 2018 & 24.00 & 25.40 & 44.40 & 43.50 & 43.60 \\
\hline & 2019 & 25.40 & 12.00 & 45.20 & 44.50 & 47.50 \\
\hline & 2020 & 22.10 & 11.80 & 41.30 & 44.80 & 50.00 \\
\hline Average & & 22.78 & 17.34 & 41.82 & 44.18 & 43.18 \\
\hline Rate of change & & $8.87 \%$ & $-7.09 \%$ & $20.41 \%$ & $2.28 \%$ & $51.98 \%$ \\
\hline \multirow{5}{*}{ Pompeu Fabra } & 2016 & 32.90 & 28.00 & 90.70 & 37.20 & 63.30 \\
\hline & 2017 & 30.30 & 33.00 & 93.10 & 40.50 & 65.10 \\
\hline & 2018 & 34.70 & 38.90 & 97.10 & 40.00 & 62.30 \\
\hline & 2019 & 40.00 & 39.10 & 95.70 & 42.40 & 64.30 \\
\hline & 2020 & 37.70 & 40.10 & 94.40 & 44.50 & 66.50 \\
\hline Average & & 35.12 & 35.82 & 94.20 & 40.92 & 64.30 \\
\hline Rate of change & & $14.59 \%$ & $43.21 \%$ & $4.08 \%$ & $19.62 \%$ & $5.06 \%$ \\
\hline \multirow{5}{*}{ Rovira i Virgili } & 2016 & 20.80 & 14.80 & 66.90 & 30.90 & 41.50 \\
\hline & 2017 & 21.50 & 15.80 & 72.10 & 35.20 & 45.50 \\
\hline & 2018 & 22.20 & 17.20 & 76.40 & 34.50 & 47.70 \\
\hline & 2019 & 24.20 & 20.20 & 76.20 & 36.00 & 49.10 \\
\hline & 2020 & 23.70 & 21.00 & 67.60 & 36.60 & 51.10 \\
\hline Average & & 22.48 & 17.80 & 71.84 & 34.64 & 46.98 \\
\hline Rate of change & & $13.94 \%$ & $41.89 \%$ & $1.05 \%$ & $18.45 \%$ & $23.13 \%$ \\
\hline \multirow{5}{*}{ Salamanca } & 2016 & 26.10 & 16.90 & 25.90 & 31.60 & 40.80 \\
\hline & 2017 & 23.30 & 14.40 & 32.20 & 35.20 & 44.50 \\
\hline & 2018 & 24.80 & 13.70 & 35.50 & 33.50 & 47.70 \\
\hline & 2019 & 27.80 & 15.20 & 33.60 & 35.60 & 49.50 \\
\hline & 2020 & 26.40 & 17.50 & 37.90 & 37.00 & 51.40 \\
\hline Average & & 25.68 & 15.54 & 33.02 & 34.58 & 46.78 \\
\hline Rate of change & & $1.15 \%$ & $3.55 \%$ & $46.33 \%$ & $17.09 \%$ & $25.98 \%$ \\
\hline
\end{tabular}




\begin{tabular}{|c|c|c|c|c|c|c|}
\hline University & Year & Teaching & Research & Citations & Industry & $\begin{array}{l}\text { Internationa- } \\
\text { lization }\end{array}$ \\
\hline \multirow{5}{*}{ Santiago de Compostela } & 2016 & 22.90 & 14.10 & 46.90 & 32.30 & 37.10 \\
\hline & 2017 & 19.80 & 14.90 & 40.90 & 35.70 & 42.40 \\
\hline & 2018 & 20.90 & 15.00 & 48.20 & 35.20 & 44.20 \\
\hline & 2019 & 26.80 & 16.00 & 50.50 & 39.00 & 44.30 \\
\hline & 2020 & 21.80 & 16.60 & 46.90 & 40.30 & 44.70 \\
\hline Average & & 22.44 & 15.32 & 46.68 & 36.50 & 42.54 \\
\hline Rate of change & & $-4.80 \%$ & $17.73 \%$ & $0.00 \%$ & $24.77 \%$ & $20.49 \%$ \\
\hline \multirow{5}{*}{ Sevilla } & 2016 & 21.50 & 14.90 & 32.60 & 36.70 & 32.00 \\
\hline & 2017 & 19.50 & 13.90 & 33.10 & 37.90 & 34.40 \\
\hline & 2018 & 20.90 & 15.40 & 35.70 & 42.80 & 34.70 \\
\hline & 2019 & 27.00 & 18.80 & 38.70 & 36.60 & 38.40 \\
\hline & 2020 & 25.40 & 18.70 & 36.50 & 36.60 & 38.20 \\
\hline Average & & 22.86 & 16.34 & 35.32 & 38.12 & 35.54 \\
\hline Rate of change & & $18.14 \%$ & $25.50 \%$ & $11.96 \%$ & $-0.27 \%$ & $19.38 \%$ \\
\hline \multirow{5}{*}{ València } & 2016 & 22.70 & 16.90 & 49.60 & 31.30 & 40.50 \\
\hline & 2017 & 20.90 & 18.40 & 50.50 & 34.40 & 41.70 \\
\hline & 2018 & 21.90 & 18.40 & 56.20 & 34.40 & 42.20 \\
\hline & 2019 & 28.00 & 19.60 & 68.00 & 36.30 & 44.90 \\
\hline & 2020 & 24.60 & 20.80 & 70.80 & 37.00 & 47.00 \\
\hline Average & & 23.62 & 18.82 & 59.02 & 34.68 & 43.26 \\
\hline Rate of change & & $8.37 \%$ & $23.08 \%$ & $42.74 \%$ & $18.21 \%$ & $16.05 \%$ \\
\hline \multirow{5}{*}{ Vigo } & 2016 & 18.40 & 10.50 & 31.80 & 38.10 & 30.70 \\
\hline & 2017 & 15.50 & 11.70 & 33.20 & 37.00 & 36.50 \\
\hline & 2018 & 19.40 & 12.20 & 32.20 & 35.70 & 40.30 \\
\hline & 2019 & 26.00 & 14.80 & 35.30 & 39.00 & 41.70 \\
\hline & 2020 & 17.70 & 14.60 & 39.50 & 38.40 & 41.60 \\
\hline Average & & 19.40 & 12.76 & 34.40 & 37.64 & 38.16 \\
\hline Rate of change & & $-3.80 \%$ & $39.05 \%$ & $24.21 \%$ & $0.79 \%$ & $35.50 \%$ \\
\hline \multirow{5}{*}{ Zaragoza } & 2016 & 20.10 & 12.70 & 49.50 & 36.70 & 33.50 \\
\hline & 2017 & 20.30 & 12.50 & 49.70 & 38.60 & 35.10 \\
\hline & 2018 & 20.50 & 12.30 & 50.80 & 37.10 & 37.60 \\
\hline & 2019 & 27.90 & 12.40 & 47.70 & 38.10 & 37.00 \\
\hline & 2020 & 22.00 & 13.40 & 43.80 & 38.60 & 39.40 \\
\hline Average & & 22.16 & 12.66 & 48.30 & 37.82 & 36.52 \\
\hline Rate of change & & $9.45 \%$ & $5.51 \%$ & $-11.52 \%$ & $5.18 \%$ & $17.61 \%$ \\
\hline
\end{tabular}

Table 5 shows that the Universitat Autònoma de Barcelona achieved the highest averages on teaching (41.56) and research (37.02). Likewise, the Universitat Pompeu Fabra obtained the highest averages on citations (94.20) and internationalization (64.30). In the variable related to industry, the Universidad de Navarra achieved the highest average (67.02) and rate of change (34.65\%). The highest percentage rates of change for the remaining variables were for the Universidad del País Vasco on teaching (20.88\%), Universitat Pompeu Fabra on research (43.21\%), Universidad de La Coruña on citations (95.78\%), and Universitat Politècnica de València on internationalization (51.98\%).

The information captured in the HJ-biplot for the first two axes is presented in Table 6. Two axes were
Table 6. Explained variance, THE ranking

\begin{tabular}{|c|c|c|c|}
\hline Axis & Eigenvalue & $\begin{array}{c}\text { Explained } \\
\text { variance }\end{array}$ & $\begin{array}{c}\text { Cumulative } \\
\text { variance }\end{array}$ \\
\hline Axis 1 & 8.98 & 67.21 & 67.21 \\
\hline Axis 2 & 4.67 & 18.20 & 85.41 \\
\hline
\end{tabular}

Table 7. Contribution of each factor axis to the variability of the indicators in the $T H E$ ranking

\begin{tabular}{|l|c|c|}
\hline Variable & Axis 1 & Axis 2 \\
\hline Teaching & 764 & 117 \\
\hline Research & 860 & 78 \\
\hline Citations & 787 & 12 \\
\hline Industry & 293 & 623 \\
\hline Internationalization & 656 & 80 \\
\hline
\end{tabular}


retained as a high cumulative inertia was achieved (85.41\%), sufficient to characterize with some certainty the positioning of the universities in the THE ranking with respect to all the variables considered.

The first factor axis contained the greatest amount of information. Therefore, the horizontal gradient is the most interesting to explain the ranking of the universities according to this multivariate latent gradient.

Table 7 presents the contribution of each factor axis to the variability of the different indicators in this ranking.

Considering the contributions of each factor to the entries in each column, all the variables could be interpreted in the factorial plane 1-2 and showed a good-quality representation. Research, citations, teaching, and internationalization made a high contribution to axis 1 . For industry, the variable related to knowledge transfer, axis 2 contributed the most information of interest.

Figure 3 shows the $\mathrm{HJ}$-biplot for the 2020 data matrix. A direct and strong correlation was observed between the teaching and research variables, both of which contribute $30 \%$ to the classification. There was also a direct covariation between both of these variables and citations and internationalization. Therefore, four of the five indicators in the ranking, with a total weighting of $97.5 \%$, correlated directly in the biplot. Industry also showed a direct interrelation with the rest of the indicators, except education, with which it did not show any connection. However, no indirect correlations appeared between any of the ranking variables.

Regarding the rows, 8 of the 25 universities analyzed were not well represented. Universities were positioned in different parts of the graph, and various groups were established based on the similarity between their characteristics.

The Universidades Pompeu Fabra and Autònoma de Barcelona were characterized by citations. Barcelona, Autónoma de Madrid, and Complutense de Madrid stood out in terms of the teaching variable, while the Universidad de Navarra obtained a high value on the industry variable. The other institutions are grouped in the left part of Figure 3, not showing good positions on any indicator of this ranking.

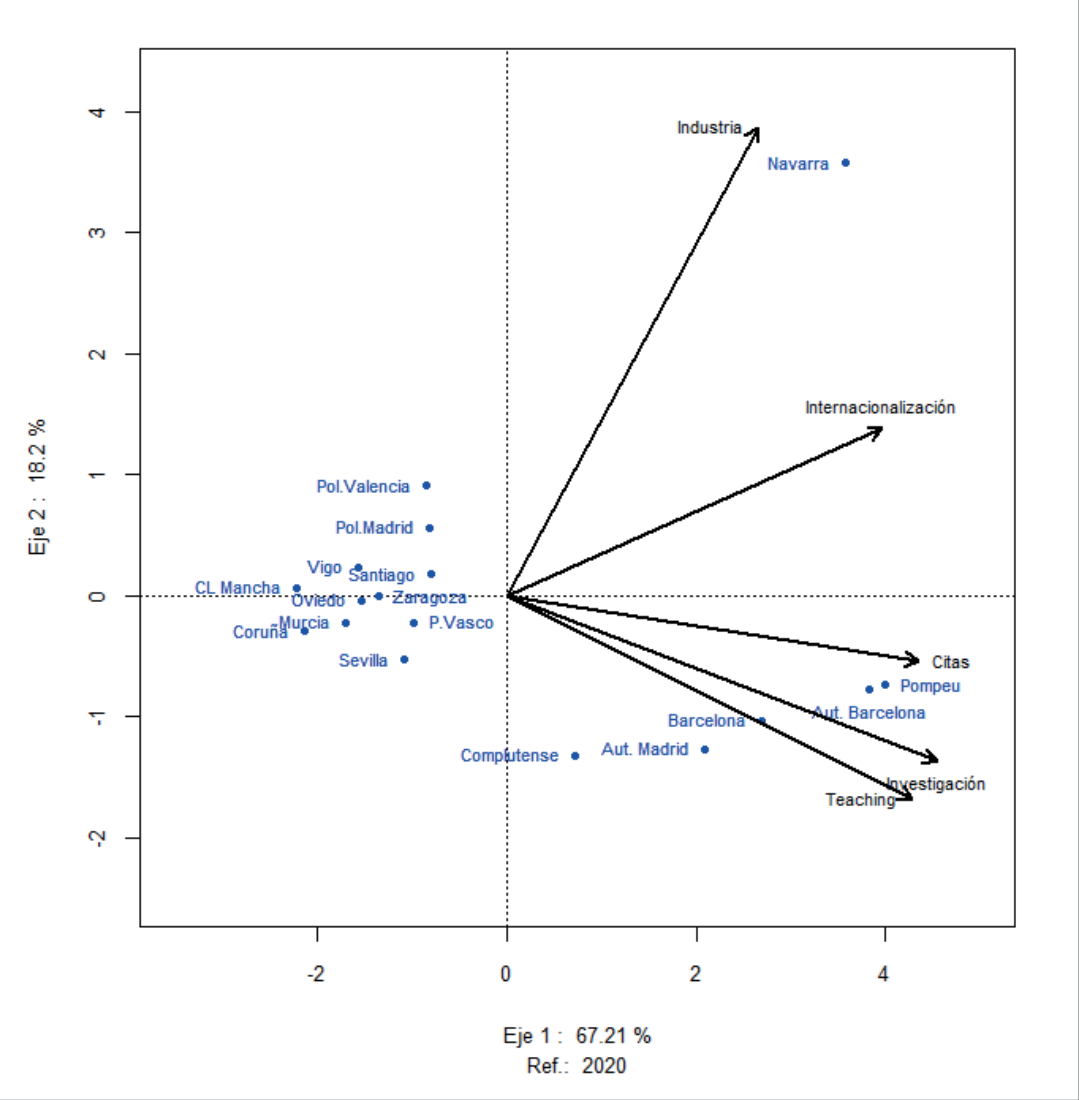

Figure 3. HJ-biplot factorial representation for the THE ranking (2020), planes 1-2.

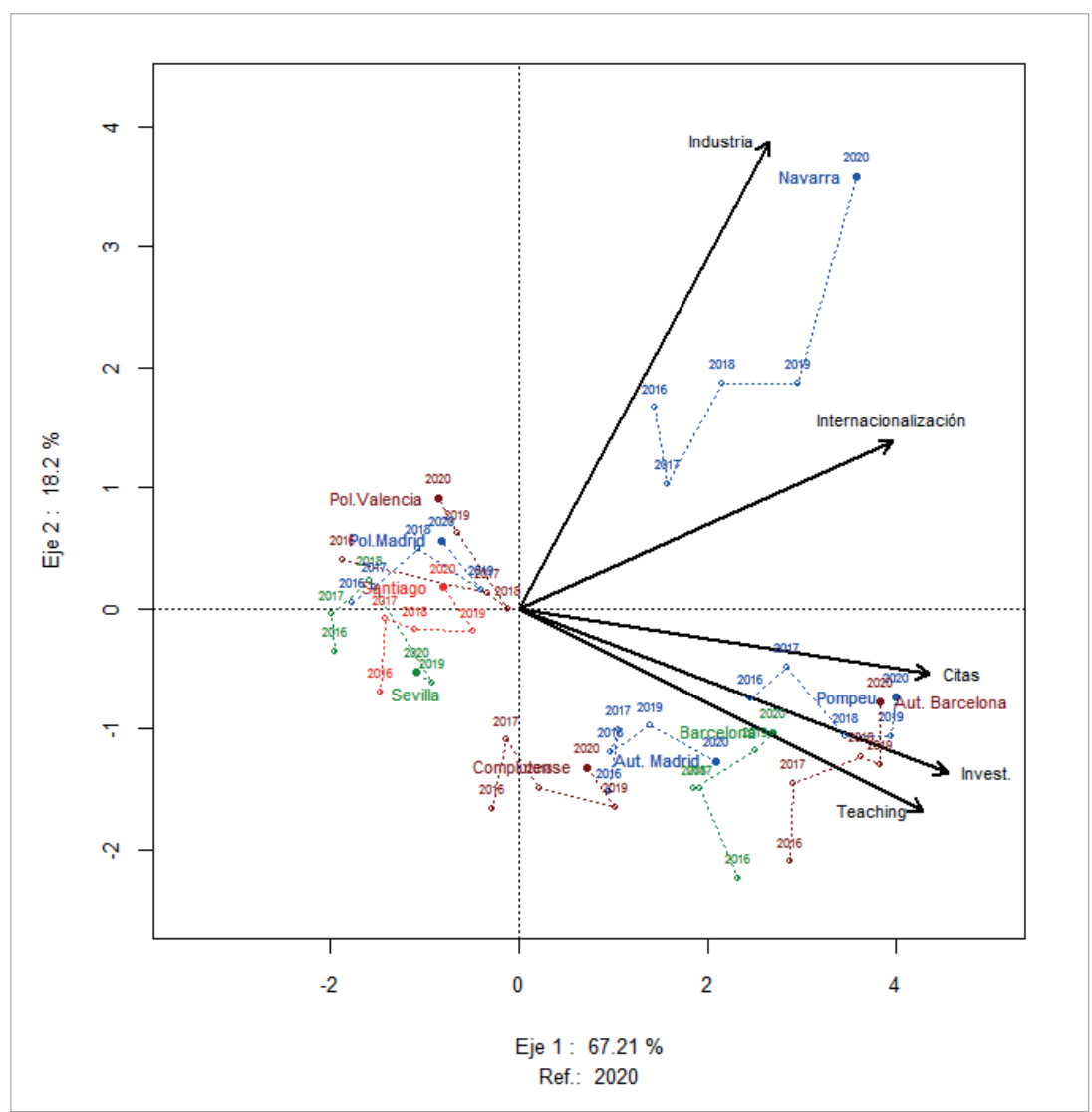

Figure 4. Dynamic biplot factorial representation of the THE ranking, plane 1-2. 
Comparison with Table 5 reveals that the highest means on citations corresponded to the Pompeu Fabra (94.20) and Autònoma de Barcelona universities (89.06), and although the rates of change were positive, they were not very high $(4.08 \%, 10.86 \%$, and $10.86 \%$, respectively). The teaching averages of the universities of Barcelona (35.92), Complutense de Madrid (35.38), and Autónoma de Madrid (34.98) were high, but the highest value on this indicator corresponded to the Universitat Autònoma de Barcelona (41.56). Regarding the rates of change, the Universitat de Barcelona was the only university with a negative value (-3.12\%). Finally, the Universidad de Navarra exhibited the highest average (67.02) and greatest increase (34.65\%) on the industry variable.

Figure 4 shows the dynamic analysis that enables a projection of the situations of the universities in each year, illustrating their trajectories.

The Universitat Pompeu Fabra, ranked first in the THE ranking, was characterized in 2016 by research, while in the following year it approached citations, only to stand out again in 2018 in research, and end again in 2020 with a high value on citations. The Universitat Autònoma de Barcelona, ranked second, also showed an upward trajectory that caused a change in its position from teaching to research, to end up characterized by citations in 2020. The trajectories of the next most highly classified universities, Barcelona and Autónoma de Madrid, approached teaching, which was also approached by the Universidad Complutense de Madrid. The Universidad de Navarra, after a decline in 2017 that brought it closer to internationalization, showed a growing trend towards industry with a very strong increase in the final year and a very distant position. The rest of the universities, albeit with changes in their trajectories, continued with more distant positions with respect to all the indicators.

\section{Conclusions and discussion}

This research demonstrates the practical utility of the dynamic biplot technique (Egido-Miguélez, 2015) to study the internationalization of Spanish universities through rankings, as well as to illustrate their trajectories. The $\mathrm{HJ}$-biplot technique (Galindo-Villardón, 1986) facilitated a graphical representation of which universities and indicators could be superimposed in the same reference system with the highest quality of representation.

The present work examined the Spanish universities classified in the ARWU and THE rankings over the last five years. A very high accumulated inertia was observed for both lists, which allowed an intuitive interpretation of the graphs.

Different covariations were observed between the variables of the two rankings. In the ARWU ranking, the strongest direct correlation was found between two indicators weighing $40 \%$ each: highly cited researchers and articles indexed in SCIE and SSCI. This latter variable also correlated directly with published articles in Nature and Science, although more weakly. In contrast, highly cited researchers was indirectly interrelated with organization size and showed little covariation with articles in Nature and Science or alumni with Nobel Prizes or Fields Medals.

However, the indicators in the THE ranking appeared to be more linked, and none of them correlated indirectly, with only knowledge transfer not showing any connection with teaching. Furthermore, the three dimensions with the largest weightings (teaching, research, and citations) were strongly and directly correlated in the biplot. Likewise, these indicators showed a direct interrelation with internationalization, and therefore four of the five THE variables were correlated, together accounting for a weighting of $97.5 \%$ in this ranking. In line with these conclusions, Safón (2019) considered that international lists include reputation biases produced by surveys that affect not only teaching but also research performance. On the one hand, the editors of the most prestigious journals may be inclined to accept more articles from the most prominent universities. On the other hand, authors also tend to attribute a higher quality to works published from these institutions, increasing their citations. This ultimately means that research and reputation feed into each other, and the position in the rankings derives not only from the current results of the university but also from past reputation, which in turn improves current research (Safón; Docampo, 2020).

Twice as many Spanish institutions were classified in the THE ranking for five consecutive years compared with the $A R W U$ ranking. In the $A R W U$ ranking, no university managed to score in the category of academics who won a Nobel Prize or Fields Medals, a variable with a weight of $20 \%$ in the classification. The ARWU ranking exhibits a highly investigative component and measures outstanding individual performance through awards or highly cited researchers. Spanish institutions have limited production of this type (Casani; Rodríguez-Pomeda, 2017), thus hindering their positioning in this ranking.
Rankings are not the only manifestation of internationalization, but competing in them brings with it prestige that is always beneficial for the organization as well as the reputation of the Spanish university system 
All the universities that managed to be classified in the ARWU ranking also did so in the THE ranking and are thus considered as centers with high transnational visibility. This visibility occurred through different variables. The category of highly cited researchers included the Universidades de Barcelona, Granada, València, and Politècnica de València. Only one Spanish university, the Universidad Complutense de Madrid, managed to score in the alumni Nobel Prize or Fields Medal winners category. Regarding knowledge transfer, the Universidad de Navarra stood out. No Spanish university was classified in the sole indicator that directly measures internationalization. The dimension valuing education, measured largely based on reputation surveys, included the Universidades de Barcelona, Autónoma de Madrid, and Complutense de Madrid. In this study, however, centers such as the Autónoma de Barcelona, Pompeu Fabra, and Barcelona stood out. The remaining 12 entities classified in the international lists did not obtain high values on any indicator and showed quite similar positions in the biplots.

It can thus be concluded that Spanish universities show a low level of internationalization, with only a small percentage having sufficient capacity to compete in global rankings. Only $29 \%$ of organizations appear continuously in one of the two most prominent and influential international rankings. Most of the universities have a weak brand with respect to the global context (Carrillo; Ruão, 2005), and only nine show high values on any of the indicators when considered in a multivariate fashion (Autònoma de Barcelona, Autónoma de Madrid, Barcelona, Complutense de Madrid, Granada, Navarra, Politècnica de València, Pompeu Fabra, and València). As more universities are added to these classifications each year, it will become necessary to analyze their trajectory over time to determine whether the prestige and reputation of the Spanish university system improve.

Although the concept of internationalization of higher education presents many nuances, and global rankings are not its only manifestation, one must not forget that they provide opportunities for greater transnational visibility (Collins; Park, 2016). All the research universities in the world follow them, worry about their orientation, and even adapt themselves in the face of methodological changes and transformations (Pérez-Esparrells, 2017). Competing in them brings with it prestige that is always beneficial for the organization as well as the reputation of the Spanish university system.

\section{References}

Carrillo, María-Victoria; Ruão, Teresa (2005). “La reputación en las universidades: de la identidad local a la reputación europea”. En: 5o Congresso de comunicação local. Universitat Jaume I de Castellón, 14-16 Dezembro, pp. 14-16. http://repositorium.sdum.uminho.pt/bitstream/1822/5666/1/Carrillo_Ruao_reputacionuniversidads_05.pdf

Casani, Fernando; Rodríguez-Pomeda, Jesús (2017). “La idea de la 'flagship university' en el nuevo contexto internacional de la educación superior". En: Pérez-Encinas, Adriana; Howard, Laura; Rumbley, Laura; De-Wit, Hans (coords.). Internacionalización de la educación superior en España. Reflexiones y perspectivas. España: Servicio Español para la Internacionalización de la Educación (Sepie).

http://sepie.es/doc/comunicacion/publicaciones/SEPIE-ESP_internacionalizacion.pdf

Collins, Francis L.; Park, Gil-Sung (2016). "Ranking and the multiplication of reputation: reflections from the frontier of globalizing higher education". Higher education, v. 72, n. 1, pp. 115-129.

https://doi.org/10.1007/s10734-015-9941-3

De-Wit, Hans (2017). “The importance of internationalization at home”. Thema, v. 5, n. 17, pp. 25-29.

De-Wit, Hans; Altbach, Philip (2020). "Internationalization in higher education: global trends and recommendations for its future". Policy reviews in higher education, first online.

https://doi.org/10.1080/23322969.2020.1820898

Delgado-Márquez, Blanca L.; Hurtado-Torres, Nuria-Esther; Bondar, Yoroslava (2011). "Internationalization of higher education: Theoretical and empirical investigation of its influence on university institution rankings". RUSC. Universities and knowledge society journal, v. 8, n. 2, pp. 101-122.

https://doi.org/10.7238/rusc.v8i2.1069

Docampo, Domingo; Cram, Lawrence (2015). “On the effects of institutional size in university classifications: the case of the Shanghai Ranking". Scientometrics, v. 102, n. 2, pp. 1325-1346.

https://doi.org/10.1007/s11192-014-1488-z

Docampo, Domingo; Herrera, Francisco; Luque-Martínez, Teodoro; Torres-Salinas, Daniel (2012). “Efecto de la agregación de universidades españolas en el Ranking de Shanghai (ARWU): caso de las comunidades autónomas y los campus de excelencia". El profesional de la información, v. 21, n. 4, pp. 428-432.

https://doi.org/10.3145/epi.2012.jul.16 
Docampo, Domingo; Torres-Salinas, Daniel (2013). “La nueva lista de investigadores altamente citados de Thomson Reuters y el Ranking Shanghai: situación de España y mapa universitario”. El profesional de la información, v. 22, n. 3, pp. $264-272$. https://doi.org/10.3145/epi.2013.may.11

Douglass, John-Aubrey (2016). The new flagship university. Changing the paradigm from global rankig to national relevancy. New York: Palgrave Macmillan. ISBN: 9781349576654

https://doi.org/10.1057/9781137500496

Douglass, John-Aubrey (2014). "Profiling the flagship university model: an exploratory proposal for changing the paradigm from ranking to relevancy". Center for studies in higher education, v. 15, n. 4, pp. 250-260.

https://escholarship.org/uc/item/8kn1m9dz

Egido-Miguélez, Jaime-Fermín (2015). Biplot dinámico. Tesis doctoral. Salamanca: Universidad de Salamanca. http://gredos.usal.es/handle/10366/125245?/ocale-attribute=en https://doi.org/10.14201/gredos.125245

Galindo-Villardón, María-Purificación (1986). “Una alternativa de representación simultánea: HJ-Biplot”. Qüestiió, v. 10, n. 1, pp. 13-23.

https://dialnet.unirioja.es/servlet/articulo?codigo $=2360880$

Knight, Jane (2014). "What is an international university?". In: Glass, Ana (ed.). The state of higher education. OECD Higher education programme. OECD, pp. 139-143.

http://www.oecd.org/education/imhe/StateofHigherEducation2014.pdf

Knight, Jane (2004). "Internationalization remodeled: definition, approaches and rationales". Journal of studies in international education, v. 8, n. 1, pp. 5-31.

https://doi.org/10.1177/1028315303260832

Locke, William; Verbik, Line; Richardson, John T. E.; King, Roger (2008). Counting what is measured or measuring what counts? League tables and their impact on higher education institutions in England. Bristol: Higher Education Funding Council for England.

http://webarchive.nationalarchives.gov.uk/20100202100434/http://www.hefce.ac.uk/pubs/hefce/2008/08_14

Luque-Martínez, Teodoro; Faraoni, Nina; Doña-Toledo, Luis (2018). “Meta-ranking de universidades. Posicionamiento de las universidades españolas". Revista española de documentación científica, v. 41, n. 1.

https://doi.org/10.3989/redc.2018.1.1456

Marginson, Simon (2007). "Global university rankings: implications in general and for Australia". Journal of higher education policy and management, v. 29, n. 2, pp. 131-142.

https://doi.org/10.1080/13600800701351660

Marginson, Simon (2012). "Global university rankings: the strategic issues". En: Las universidades latinoamericanas ante los rankings internacionales: impactos, alcances y límites. UNAM, 17 y 18 de mayo.

http://www.encuentro-rankings.unam.mx/Documentos/ConferenciaMagistralMarginsontexto.pdf

Marginson, Simon (2014). "University rankings and social science". European journal of education, v. 49, n. 1, pp. $45-59$. https://doi.org/10.1111/ejed.12061

Montané-López, Alejandra; Beltrán-Llavador, José; Teodoro, António (2017). “La medida de la calidad educativa: acerca de los rankings universitarios". Revista de la asociación de sociología de la educación, v. 10, n. 2, pp. 283-300. https://doi.org/10.7203/rase.10.2.10145

Ordorika, Imanol (2015). "Rankings universitarios". Revista de la educación superior, v. 44, n. 173, pp. 7-9. https://doi.org/10.1016/j.resu.2015.04.009

Ordorika, Imanol; Rodríguez-Gómez, Roberto (2010). “El ranking Times en el mercado del prestigio universitario". Perfiles educativos, v. 32, n. 129, pp. 8-28.

https://doi.org/10.22201/iisue.24486167e.2010.129.18918

Pérez-Esparrells, Carmen (2017). "La reputación de las universidades a través de los rankings globales". Nueva revista de política, cultura y arte, n. 163, pp. 224-236.

https://www.nuevarevista.net/universidad/la-reputacion-las-universidades-traves-los-rankings-globales

Rauhvargers, Andrejs (2011). Global university rankings and their impact. Brussels: European University Association. ISBN: 9789078997276

http://www.eua.eu/downloads/publications/global\%20university\%20rankings\%20and\%20their\%20impact.pdf

Rodríguez-Espinar, Sebastián (2018). “La universidad: una vision desde 'fuera' orientada al futuro”. Revista de investigación educativa, v. 36, n. 1, pp. 15-38.

https://doi.org/10.6018/rie.36.1.309041 
Safón, Vicente (2012). "Análisis de los factores subyacentes en los rankings internacionales de universidades". Regional and sectoral economic studies, v. 12, n. 3, pp. 193-208.

Safón, Vicente (2019). "Inter-ranking reputational effects: an analysis of the Academic Ranking of World Universities (ARWU) and the Times Higher Education world university rankings (THE) reputational relationship". Scientometrics, v. 121, n. 2, pp. 897-915.

https://doi.org/10.1007/s11192-019-03214-9

Safón, Vicente; Docampo, Domingo (2020). "Analyzing the impact of reputational bias on global university rankings based on objective research performance data: the case of the Shanghai Ranking (ARWU)". Scientometrics, v. 125, n. 3, pp. 2199-2227.

https://doi.org/10.1007/s11192-020-03722-z

Sanz-Casado, Elías (2015). Guía de buenas prácticas para la participación de las universidades españolas en los rankings internacionales. Madrid: Secretaría General Técnica. Subdirección General de Documentación y Publicaciones.

http://sede.educacion.gob.es/publiventa/guia-de-buenas-practicas-para-la-participacion-de-las-universidadesespanolas-en-los-rankings-internacionales/universidad-espana/20227

Shehatta, Ibrahim; Mahmood, Khalid (2016). "Correlation among top 100 universities in the major six global rankings: policy implications". Scientometrics, v. 109, n. 2, pp. 1231-1254.

https://doi.org/10.1007/s11192-016-2065-4

Tomàs-Folch, Marina; Feixas-Condom, Mònica; Bernabeu, Maria-Dolors; Ruiz, José-María (2015). “La literatura científica sobre rankings universitarios: una revisión sistemática". Revista de docencia universitaria, v. 13, n. 3, pp. 33-54. https://doi.org/10.4995/redu.2015.5418

Vázquez-García, Juan-Antonio (2015). "Nuevos escenarios y tendencias universitarias". Revista de investigación educativa, v. 33, n. 1, pp. 13-26.

https://doi.org/10.6018/rie.33.1.211501

Yong-Amaya, Linda-Evelyn; Zambrano-Zambrano, Juverly; Ruso-Armada, Frida (2018). "La excelencia en los sistemas de educación superior". Cofín Habana, v. 12, n. 1, pp. 1-14.

http://scielo.s/d.cu/scielo.php?script=sci_arttext\&pid=S2073-60612018000100001

\section{Inforảrea}

\section{Ayudamos a tu organización en la transformación digital y el gobierno de la información}

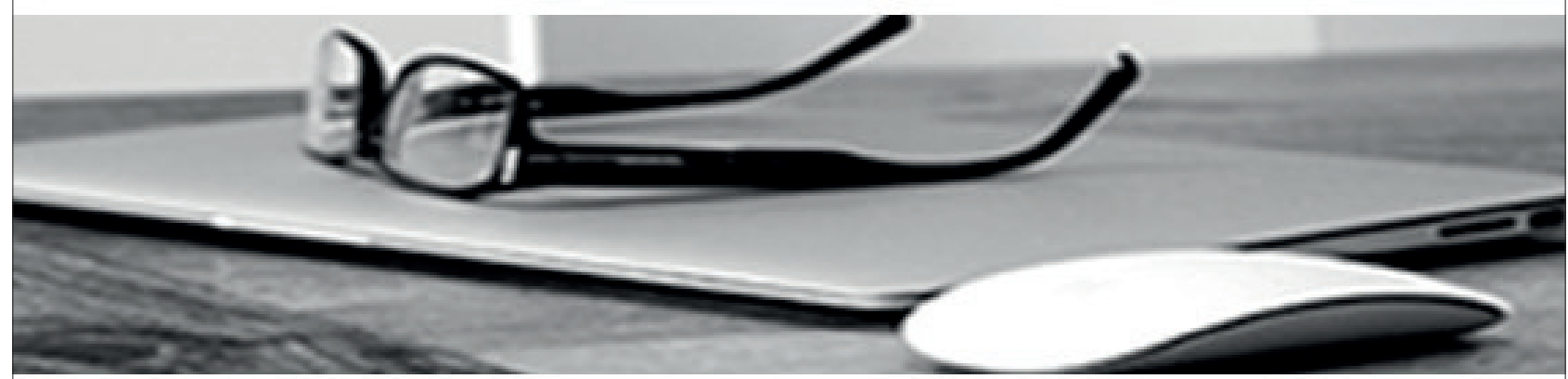

* Consultoría estratégica en gestión y gobierno de la información

* Gestión documental y "records management"

* Gestión de contenidos, intranets corporativas y entornos de colaboración

* Estudios especializados

Clientes satisfechos, cientos de empresas nacionales e internacionales y más de 30 años de experiencia son la mejor garantía de nuestra reputación. 